\title{
The Role of Teachers and Principals In Improving the Quality of Learning
}

\author{
Nurhasanah $^{1}$, Bukman Lian ${ }^{2}$, Mulyadi $^{3}$ \\ ${ }^{1}$ SD Negeri 5 Selat Penuguan, \\ ${ }^{2,3}$ Universitas PGRI Palembang \\ (cc) EY
}

\begin{abstract}
This study aimed at determining the role of teachers and principals in improving the quality of learning in elementary school of Pulau Rimau. The sample in this study were 40 teachers from Pulau Rimau. The data were collected using 1) interviews, 2) observations, and 3) documentation. Research data analysis techniques include 1) data reduction, 2) data presentation, and 3) data verification. The results showed that teachers and principals have a role in improving the quality of education of SD Negeri in Pulau Rimau.
\end{abstract}

Keywords - acher's Role, Principal, Quality of Learning

\section{INTRODUCTION}

The quality of education is one of the benchmarks that determine the dignity or progress of a nation. By looking at the quality of education of country, a person will be able to estimate the country's ranking among the countries in the world (Tobari et al, 2018; Lian et al, 2018; Andriani et al, 2018; Apriana et al, 2019). Therefore, the developed nation will always pay great attention to the world of education, by making various efforts to improve the quality of education, such as increasing the educational budget, holding various competitions in various aspects of education, or sending the national buds to study in other countries. These various efforts were made because the awareness of the importance of education, and the belief that a nation that neglects education will become a nation that is left behind, which will be unable to compete with other nations (Kurniasih, 2017; Septiani et al, 2019).

According to a Political and Economic Risk Consultant (PERC) survey, the quality of education in Indonesia ranks 12 th out of 12 countries in Asia. Indonesia's position is under Vietnam. Data reported by The World Economic
Forum Sweden (2000), Indonesia has low competitiveness, which only ranks 37 from 57 countries surveyed in the world. And still according to a survey from the same institution, Indonesia is only predicated as a follower not as a technology leader from 53 countries in the world.

The cause of the low quality of education in Indonesia certainly cannot be separated from the role of teachers and principals as their top leaders (Irmayani et al, 2018; Salwa et al, 2019; Sarina et al, 2019). Seeing the importance of the principal's function, to improve higher performance is not an easy job for the principal because the activity takes place in a long process that is well planned and programmed as well. But in reality, not a few school principals only act as formality leaders in a system, just as structural office holders while waiting for their retirement.

Furthermore according to Kristiawan (2017) if teachers and staff have a high work spirit, are creative, are open, then one of the functions of the principal as an education leader to improve the quality of education will run well (Renata et al, 2018; Murtiningsih et al, 2019). This situation is determined by the form and nature of leadership by the 
principal, so that the teacher becomes professional (Apriana et al, 2019).

The teacher is an educator whose main task is teaching, in the sense of developing the realm of creativity, taste and intention of students as the ideal concept of educating implementation. Teacher personality characteristics include: cognitive flexibility, and psychological openness. We hope that teachers will be able to compete and work professionally. Teacher's competence is the ability in carrying out their profession, while professionalism means the special qualities and behaviours that characterize professional teachers are also expected to be able to carry out KBM an integral and reciprocal activity between teachers and students in instructional situations. In this situation the teacher teaches and students learn (Zahroh, 2015).

In accordance with the Law Number 20 year 2003, concerning the National Education System, the position of teacher as an educator is a professional position. For this reason, teacher professionalism is demanded to continue to develop in accordance with the changing times, science and technology, as well as the needs of the community including the need for quality human resources and capability to be able to compete in regional, national and international forums (Sani, 2017).

The role of teachers and principals is assessed in terms of performance which results in outcomes for the organization and rewards for personnel in the form of salaries, benefits, job guarantees, and recognition from superiors and promotional opportunities for individual employees (Khasanah et al, 2019). This is in line with motivator factors and health factors. Employees in general often measure job satisfaction from this reward angle, which is the most tangible thing they receive from work. Individual bus a get job satisfaction from their personal sense of accomplishment through work and also from feedback on their performance (Zahroh, 2015).

Assessment must create an accurate picture of the role of the teacher and the principal through the typical work of the individual. This means that job descriptions especially in teaching functions and teaching (both qualitative and quantitative) standards are absolute. The assessment is not done just to reveal the results of a poor work of teachers and principals. Acceptable and good results must be identified so they can be strengthened. To achieve this goal, the assessment system must be job-related and practical, include standards, and use reliable measures. Job-related means that the system evaluates important behaviours that determine job success (job analysis). If the evaluation is not work related, it is invalid. In this context the assessment of teachers and principals in carrying out daily tasks by students is theoretically sufficient (Zahroh, 2015).

This assessment is considered more effective when it is objective, uses appropriate techniques, actively engages employees, is well understood, and is an accepted management responsibility. Ideally, evaluating the roles of teachers and principals is based on documented performance that is measured throughout the assessment time for each of the established standards or objectives related to the strategy for the job. But studies show that performance evaluation is usually very subjective, even though formal systems are used. The appraiser may not have all the relevant facts regarding work conditions, the actual qualities of individual behaviour, and the relative standards between assessments. (Zahroh, 2015).

In Banyuasin Regency, particularly in rayon 01 Subdistrict of Pulau Rimau there are 17 (Seventeen) Public Elementary Schools scattered in several villages on Pulau Rimau, Banyuasin Regency. Based on the results of the researchers' initial interview with the Rayon supervisor 01 of Pulau Rimau, Mr. Slamet Kusnadi, S.Pd.M.Si on April 22, 2019, the Rayon 01 supervisor of Rimau explained that the role of teachers and principals in improving the quality of student learning was considered good, but needs to be improved again. This is because there are still many obstacles that must be addressed, such as school facilities and infrastructure considered inadequate. For facilities and infrastructure, I as the supervisor of rayon 01 Sub-district of Pulau Rimau must receive reports from schools about the obstacles they are facing. Now this report can be said to have not been received, both verbally and in writing.

Besides that, the obstacle faced is that there are still many teachers who teach at SD Negeri Pulau Rimau District on rayon 01 do not understand the importance of teaching programs such as RPP related to Curriculum 13. This should already be programmed, because the learning process has led to maximum student activity. The teacher is only a facilitator in the learning process. In the process, there are some teachers who teach need to be done periodically coaching through coaching from the principal so that the results achieved are the quality of education can be improved again for the progress of the school as there are still many honorary teacher statuses, inadequate teacher expertise, school infrastructure and facilities are still deemed inappropriate, teaching hours are still not optimal, provisioning of teachers through training and education. 
Armed with the explanation above, the reason researchers chose this title and their great hopes in the future can be used as study material for improving the quality of SD Negeri in Pulau Rimau. In addition, there are also no other researchers who conducted a similar study, "The Role of Teachers and Principals in Improving the Quality of Learning of Primary School Students on Pulau Rimau".

Based on the results of the interviews that have been stated above, the identification of problems identified in this study can be identified 1) the role of teachers and principals in improving the quality of student learning is not optimal; 2) there are still teachers who use KTSP 2006 in the learning process; 3 ) teachers who teach more dominate the conventional approach with lectures, questions and answers and assignments; 4) educational facilities in schools are considered not feasible. Given the breadth of problems in this study, the limitations of the research problem are as follows; 1) inadequate teacher expertise and in accordance with the field of scientific discipline; 2) the learning process that is given must vary; 3 ) inadequate school infrastructure and facilities; 4) the quality of primary school student learning on Pulau Rimau has not yet reached satisfactory results.

Based on the background of the problem and identification, then the problem can be formulated, namely how is the role of teachers and principals in improving the quality of learning of elementary school students on Pulau Rimau? This study aims to determine the role of teachers and principals in improving the quality of learning of elementary school students on Pulau Rimau.

\section{MethodS}

This research is qualitative with the aim to gain an understanding and in-depth interpretation of the meaning of phenomena in the field. A qualitative approach is a process of research and understanding based on methodologies that investigate social phenomena and human problems. In this approach, the researcher makes a complex picture, examines words, detailed reports from the respondents' views, and conducts studies in natural situations.

While the nature or category in this study is an evaluation study using a case study methodology. Case studies aim to 1) produce a detailed description of a phenomenon; 2) developing explanations that can be given from a case study; 3) evaluating phenomena. Case study research is a study that explores a problem with detailed limitations, has in-depth data retrieval, and includes various sources of information. This research is limited by time and place, and cases studied in the form of programs, events, activities, or individuals. Moleong (2007) argues that research that has qualitative research is research conducted by observing, and carried out in a natural setting or overall context, and the main data collection tool is research itself. Furthermore Sudaryono (2009) argues that the research method is the means adopted in achieving the objectives. Furthermore, Arikunto (2010) stated the research method is a method used by researchers in collecting research data. Furthermore Djamarah (2010) stated that the method is interpreted as a means used to achieve the goals set.

Based on the description stated above, this research method is a qualitative descriptive method. Qualitative methods are used to analyse data in the form of information, such as observations, documentation, using two ways of thinking, namely as follows; 1) think deductive. Deductive thinking is a way of thinking that departs from knowledge that is general in nature and starts with general knowledge that wants to assess a particular activity (Hadi, 2011); 2) inductive thinking Inductive thinking is a way of thinking that departs from specific facts, concrete events, then from general concrete facts drawn general generalizations (Hadi, 2011). Thus, this study refers to direct observations made by researchers in collecting research data, so that the data and validity of the study are truly valid for research.

Based on the opinion of Sugiyono, the researchers took a sample that truly represented the population, namely the teachers who taught on Rayon 01 Pulau Rimau with 40 teachers consisting of 21 PNS and 19 Non PNS teachers spread across several villages. and districts within the Pulau Rimau region. For more details can be seen in the following table.

The questions in this study were addressed to each headmaster with a total of 3 (three) headmasters and 40 teachers in each school that were used as the research site. Arikunto (2010) argues that in a study data is needed. In collecting data, techniques are needed, both techniques in providing data and techniques am classifying the data that has been collected. A similar sentiment was also stated by Sugiyono (2009) that the data collection method is a method used to collect data, while the data collection technique is the method adopted in carrying out the chosen method. In short it can be said that the method is the way, while the technique is a way to run the method that has been selected.

Data that has been collected cannot be directly presented in research reports, but must be processed and analysed first. Data analysis is made after the data and information obtained in accordance with needs are compiled, classified and formulated on the basis of data interpretation. Miles and 
Humberman in Sugiyono (2015) suggested that "qualitative data analysis is an on-going, repeated and continuous effort. According to them there are three stages of data analysis namely: data reduction, display or presentation of data as well as drawing conclusions and data verification". Based on the opinion above, the stages of qualitative data analysis are: 1) Data Reduction, 2) Presentation of Data, 3) Taking Conclusions and Verifying Data. According to Moleong (2007) stated that the criteria for the validity of the data there are four types, namely: 1) creditability; 2) transferability; 3) dependability; 4) conformability.

\section{RESUlts AND Discussion}

Based on the results of research obtained about the role teachers and school principals in improving the quality of SDN learning on Pulau Rimau, it can be said that teachers and school principals have played a role in improving the learning quality of SDN students on Pulau Rimau. This is evident from the results of the research obtained can be said to have been good and in accordance with the vision, mission and goals of education in schools.

The role of the teacher in conducting guidance and counseling to improve the quality of learning of SD Negeri in Pulau Rimau obtained a value of $82.50 \%$. Thus, it can be said that the teacher has a role in providing guidance and counselling to improve the quality of learning of SD Negeri in Pulau Rimau said to be Good (B). Based on the results of research the role of school principals in improving the quality of SD Negeri in Pulau Rimau, it is known that SD Negeri School Principals in Pulau Rimau have a role in planning work goals and making school policies in accordance with the vision and mission. The policy carried out by the Principal of SD Negeri in Pulau Rimau follows the situation and conditions that must be carried out. The Principal of SD Negeri in Pulau Rimau in carrying out their duties as school leaders regulates the tasks of teachers and divides tasks in implementing learning activities at school. Evidenced by the learning process has been running effectively and efficiently. The SD Negeri Principal in Pulau Rimau always supervises school activities to improve the quality of student learning, both directing the teacher, guiding the teacher and explaining the main tasks of the teacher in teaching. Evidenced by the learning activities, the principal always provides direction, guidance and conducts class visits.

As an educator, the SD Negeri Principal in Pulau Rimau constantly guides and directs students especially during ceremonies, guides teachers in carrying out teaching assignments, always follows the development of education, both technology and information that is constantly being updated. As a manager, the SD Negeri Principal in Pulau Rimau has tried and managed the school well, and increased teacher resources to achieve learning goals effectively and efficiently. Besides that, the SD Negeri principal in Pulau Rimau has tried and tried to form a good school organization and was assisted by the school committee, as well as optimizing the existing educational advice. As administrator, the SD Negeri Principal in Pulau Rimau plays a role in managing teacher resources to achieve effective and efficient institutional goals by: 1) compiling work programs; 2) arrange a school organization; 3) move the teacher in carrying out the task professionally; 4) optimize the existing learning tools. As a supervisor, the SD Negeri Principal in Pulau Rimau plays an active role through supervision. The principal has helped develop teacher professionalism in teaching, carry out supervision programs on an on-going basis evaluate the work that has been done.

As a leader, the Principal of the SD Negeri in Pulau Rimau always tries and tries to do the best to achieve a better quality of learning. Control and move the teacher in carrying out teaching assignments. Determine policies and the best steps in the education process in schools, provide transparent and professional services and understand the conditions of school residents. As an innovator, SD Negeri Principals in Pulau Rimau always try and strive to provide good ideas in improving the quality of learning, especially to teachers who are central to students in receiving subject matter, the principal always conveys new things to teachers for student learning progress. As a motivator, SD Negeri Principals in Pulau Rimau have tried and endeavoured to give work motivation to teachers to always give their best to students in conveying the learning process and to motivate students to always learn for the student's own learning outcomes, besides that the school principal always providing direction and motivation to administrative and administrative staff. As an entrepreneur, the Principal of the SD Negeri in Pulau Rimau always sees the development of education for the progress of the school he leads and provides the best for teachers and students in activities at school to achieve the quality of learning as expected. Based on the results of the study it can be said that the principal has a role in improving the quality of learning of SD Negeri in Pulau Rimau.

\section{Conclusion}

Based on the results of the study it can be concluded that teachers and principals have a role in improving the quality 
of education of SD Negeri in Pulau Rimau. In the learning process carried out to improve the quality of learning of SD Negeri in Pulau Rimau which includes: 1) Planning Learning Activities; 2) Carry out Learning Activities; 3) Evaluating Learning Outcomes; 4) following up on the Learning Outcomes; 5) Conduct Guidance and Counselling. The role of the teacher in planning learning activities to improve the quality of learning of SD Negeri in Pulau Rimau is said to be Good (B). The role of the teacher in carrying out learning activities to improve the quality of learning of SD Negeri in Pulau Rimau is said to be Good (B). The role of the teacher in evaluating learning outcomes to improve the quality of learning of SD Negeri in Pulau Rimau is said to be Good (B). The role of the teacher in following up learning outcomes to improve the quality of learning of SD Negeri in Pulau Rimau is said to be Very Good (A). The role of the teacher in conducting guidance and counselling to improve the quality of learning of SD Negeri in Pulau Rimau is said to be Good (B). Based on the results of research the role of school principals in improving the quality of learning SD Negeri in Pulau Rimau it is known that it is said to have played a role in improving the learning quality of SD Negeri in Pulau Rimau. SD Negeri Principals in Pulau Rimau have played a role in planning work goals and making school policies according to their vision and mission. The policy carried out by the Principal of SD Negeri in Pulau Rimau follows the situation and conditions that must be carried out. The Principal of SD Negeri in Pulau Rimau in carrying out their duties as school leaders regulates the tasks of teachers and divides tasks in implementing learning activities at school. Evidenced by the learning process has been running effectively and efficiently. The SD Negeri Principal in Pulau Rimau always supervises school activities to improve the quality of student learning, both directing the teacher, guiding the teacher and explaining the main tasks of the teacher in teaching. Evidenced by the learning activities, the principal always provides direction, guidance and conducts class visits.

\section{ACKNOWLEDGMENT}

We would like to express our special thanks and gratitude to Rector Universitas PGRI Palembang, Director of Graduate Program Universitas PGRI Palembang, and Principal SD Negeri 5 Selat Penuguan who gave us the support to do this wonderful project. This project was funded independent. Secondly, we would also like to thank our friends and teachers in Graduate Program of Educational Management and SD Negeri 5 Selat Penuguan who helped us a lot in finalizing this project within the limited time frame.

\section{REFERENCES}

[1] Andriani, S., Kesumawati, N., \& Kristiawan, M. (2018). The Influence of the Transformational Leadership and Work Motivation on Teachers Performance. International Journal of Scientific \& Technology Research, 7(7).

[2] Apriana, D., Kristiawan, M., \& Wardiah, D. (2019). Headmaster's Competency In Preparing Vocational School Students For Entrepreneurship. International Journal of Scientific \& Technology Research, 8(8).

[3] Arikunto, S. (2010). Prosedur Penelitian Suatu Pendekatan Praktek [Research Procedure A Practice Approach]. Edisi Revisi. Jakarta: Rineka Cipta.

[4] Djamarah, S. B. (2015). Guru dan Anak Didik dalam Interaksi Eduaktif. Suatu Pendekatan Teoritis Psikologi [Teachers and Students in Eduactive Interactions. A Theoretical Approach to Psychology]. Jakarta: Rineka Cipta.

[5] Hadi, S. (2011). Penelitian Kualitatif [Qualitative Research]. Bandung: Alfabeta.

[6] Irmayani, H., Wardiah, D., \& Kristiawan, M. (2018). The Strategy of SD Pusri In Improving Educational Quality. International Journal of Scientific \& Technology Research, 7(7).

[7] Khasanah, U., Kristiawan, M., \& Tobari. (2019). The Implementation of Principals' Academic Supervision In Improving Teachers' Professionalism in the State Primary Schools. International Journal of Scientific \& Technology Research, 8(8).

[8] Kristiawan, M. (2017). Manajemen Pendidikan [Education Management]. Yogyakarta: Deepublish.

[9] Kurniasih, I. (2015). Kompetensi Pedagogik, Teori dan Praktik Untuk Peningkatan Kinerja dan Kualitas Guru [Pedagogic Competence, Theory and Practice for Improving Teacher Performance and Quality]. Jakarta: Kata Pena

[10] Law Number 20 Year 2003 About Education National System.

[11]Lian, B., Kristiawan, M., \& Fitriya, R. (2018). Giving Creativity Room to Students through the Friendly School's Program. International Journal of Scientific \& Technology Research, 7(7).

[12]Moleong. L.J. (2007). Metodologi Penelitian [Research Methodology]. Bandung: Sinar Baru.

[13] Murtiningsih, M., Kristiawan, M., \& Lian, B. (2019). The Correlation Between Supervision of Headmaster and Interpersonal Communication With Work Ethos of the Teacher. European Journal of Education Studies. 
[14] Salwa., Kristiawan, M., \& Lian, B. (2019). The Effect of Academic Qualification, Work Experience and Work Motivation towards Primary School Principal Performance. International Journal of Scientific \& Technology Research, 8(8).

[15] Sani, B. (2017). Kompetensi Pedagogik, Teori dan Praktik Untuk Peningkatan Kinerja dan Kualitas Guru. Jakarta: Kata Pena.

[16] Sarina., Kristiawan, M., \& Wardiah, D. (2019). Module Development the Utilization of Patchwork Fabric As Teaching Materials Crafts on the Subjects of Craft and Entrepreneurship For High School Students. International Journal of Scientific \& Technology Research, 8(5).

[17] Septiani, S., Kristiawan, M., \& Fitria, H. (2019). The Model of Berasanan Culture and its Implementation in Learning to Improve Students' Motivation. Jurnal Ilmiah Ilmu Administrasi Publik, 9(1), 37-56.

[18] Sudaryono. (2009). Penelitian Kualitatif [Qualitative Research]. Bandung: Alfabeta.

[19] Sugiyono. (2015). Memahami Penelitian Kualitatif [Understanding Qualitative Research]. Alfabeta. Bandung.

[20] Tobari., Kristiawan, M., \& Asvio, N. (2018). The Strategy of Headmaster on Upgrading Educational Quality In Asean Economic Community (AEC) Era. International Journal of Scientific \& Technology Research, 7(4).

[21]Zahroh, A. (2015). Membangun Kualitas Pembelajaran Melalui Dimensi Profesionalisme Guru. Bandung: Yrama Widya. 